\title{
A STUDY ON THE INCIDENCE OF PLEUROPULMONARY MANIFESTATIONS OF RHEUMATOID ARTHRITIS IN A GOVERNMENT GENERAL HOSPITAL, NIZAMABAD
}

\author{
L. Ramulu1 ${ }^{1}$ Ambapurkar Mukund Madhukar ${ }^{2}$
}

${ }^{1}$ Assistant Professor, Department of Orthopaedics, GMC, Nizamabad.

${ }^{2}$ Assistant Professor, Department of General Medicine, GMC, Nizamabad.

\section{ABSTRACT}

\section{BACKGROUND}

Rheumatoid Arthritis (RA) is a long-lasting autoimmune disorder that primarily affects joints. It typically results in warm, swollen and painful joints. Pain and stiffness often worsen following rest. Most commonly, the wrist and hands are involved with the same joints typically involved on both sides of the body. The disease may also affect other parts of the body.

The objectives of this study is to study the pulmonary manifestations of rheumatoid arthritis in the study population.

\section{MATERIALS AND METHODS}

This prospective study was carried out at GMC, Nizamabad. The study was conducted from April 2015 to April 2015.

\section{RESULTS}

In the present study, females are more suffering with RA (57.5\%) when compared to males (42.5\%). In the present study, the commonest age group of patients in the present study is between 40 to 50 years with a range of 30 - 60 years. All 80 patients had polyarthritis, out of which 23 patients (28.75\%) had deformities, out of which 7 were males and 16 were females. Felty's syndrome was present in 7 patients, uveitis was seen in 2 patients, vasculitis in 2 patients and pericardial effusion was seen in 3 patients. Though Rheumatoid Arthritis is common in females, pleuropulmonary manifestations are relatively common in males.

\section{CONCLUSION}

Rheumatoid arthritis usually appears during third to fifth decades of life. Their prevalence increases with age. Those patients who had long-standing disease had more articular deformities. Factors associated with poor prognosis in rheumatoid arthritis include insidious polyarticular onset, male patients, extra-articular manifestations. Rheumatoid arthritis is prevalent in females, but pleuropulmonary manifestations are common in males. Prevalence of pleuropulmonary manifestations is independent of duration of rheumatoid arthritis and presence of levels of antinuclear antibodies and C-reactive protein. But presence of pleuropulmonary manifestations indicate the severity of disease process. They are more common in patients who are having high titres of rheumatoid factor and subcutaneous nodules. Among all pleuropulmonary manifestations, pleural effusion is the most prevalent followed by diffuse interstitial fibrosis and bronchiectasis.

\section{KEYWORDS}

Rheumatoid Arthritis, Pleuropulmonary, Rheumatoid Factor, Interstitial Fibrosis.

HOW TO CITE THIS ARTICLE: Ramulu L, Madhukar AM. A study on the incidence of pleuropulmonary manifestations of rheumatoid arthritis in a Government General Hospital, Nizamabad. J. Evolution Med. Dent. Sci. 2017;6(4):334-336, DOI: $10.14260 /$ Jemds/2017/74

\section{BACKGROUND}

Rheumatoid Arthritis (RA) is a long-lasting autoimmune disorder that primarily affects joints. It typically results in warm, swollen and painful joints. Pain and stiffness often worsen following rest. Most commonly, the wrist and hands are involved with the same joints typically involved on both sides of the body. The disease may also affect other parts of the body. Patients with rheumatoid arthritis who have high titre of Rheumatoid factor, i.e. autoantibodies to the Fc component of IgG are most likely to have extra-articular manifestations of disease including rheumatoid nodule, pleuropulmonary, neurological, gastrointestinal, cardiovascular, cutaneous, haematological and ocular

Financial or Other, Competing Interest: None.

Submission 07-12-2016, Peer Review 01-01-2017,

Acceptance 06-01-2017, Published 12-01-2017.

Corresponding Author:

Dr. L. Ramulu,

Assistant Professor, Department of Orthopaedics,

GMC, Nizamabad.

E-mail:drramulul@gmail.com

DOI: $10.14260 /$ jemds $/ 2017 / 74$ complications. Prevalence of rheumatoid arthritis is $0.8 \%$. All races are affected and women are three times more likely than men to be affected. Onset of illness is most frequently in fourth and fifth decade of life. Pulmonary manifestations in rheumatoid arthritis are varied as the pleura, lung parenchyma, airway and pulmonary vasculature all can be involved. Not only the disease per se, but the treatment of rheumatoid arthritis with chemotherapeutic drugs and disease modifying anti-rheumatic drugs can also cause varied pulmonary manifestations.

Fibrosis of the lungs is a recognised response to rheumatoid disease. It is also a rare but well-recognised consequence of therapy (For example with methotrexate and leflunomide). Caplan's syndrome describes lung nodules in individuals with RA and additional exposure to coal dust. Pleural effusions are also associated with RA. Another complication of RA is Rheumatoid Lung Disease. It is estimated that about one-quarter of Americans with RA develop Rheumatoid Lung Disease. ${ }^{1}$

Present study is undertaken to know the varied pleuropulmonary manifestations of rheumatoid arthritis. 
Aims and Objectives

To study the pulmonary manifestations of rheumatoid arthritis in the study population.

\section{MATERIALS AND METHODS}

This is a prospective hospital-based study conducted in GMC, Nizamabad, Telangana. A total of 80 patients of Rheumatoid Arthritis were recruited into the study. Patients who are attending orthopaedic outpatient department from April 2015 to April 2016. The 2010 American College of Rheumatology criteria 6 was used to recruit the patients. In the present study, pleuropulmonary manifestations are studied in 80 patients who are having rheumatoid arthritis.

\section{Inclusion Criteria}

All patients of Rheumatoid Arthritis who are more than 15 years of age and who have been screened for pulmonary manifestations in both symptomatic and asymptomatic patients.

\section{Exclusion Criteria}

Juvenile Rheumatoid Arthritis, Seronegative Rheumatoid Arthritis who are not willing to give consent.

\section{Materials and Methods}

The study population included patients with rheumatoid arthritis who are more than 15 years of age. A detailed history and clinical examination was performed with special emphasis on the respiratory system. Routine investigations included are haemogram, ESR, urine microscopy, blood area, serum creatinine, serum electrolytes, liver function tests, serum total proteins, serum albumin and serum calcium were done. Ultrasound abdomen, 2D Echo and colour Doppler of arterial and venous system of both lower limbs included, wherever relevant serological tests including rheumatoid arthritis factor, C-reactive protein, ASO titres, sputum microscopy, gram stain, Ziehl-Neelsen staining for acid fast bacilli and culture and sensitivity was done on the sputum. Pleural fluid analysis including sugar, protein, lactate dehydrogenase, albumin, amylase, adenine deaminase, cell count and differential count, gram stain, acid fast bacilli stain and culture were done. Special investigations like pleural fluid $\mathrm{pH}$ and PCR for tuberculosis were done. Pulmonary function tests, chest x-ray and HRCT chest were performed and bronchoscopy was done in required cases.

\section{RESULTS}

\begin{tabular}{|c|c|c|}
\hline Sex & Total & Percentage \\
\hline Male & 34 & 42.5 \\
\hline Female & 46 & 57.5 \\
\hline \multicolumn{2}{|c|}{ Table 1. Sex Wise Distribution of Study Population } \\
\hline
\end{tabular}

In the present study, females are suffering more with RA (57.5\%) when compared with males $(42.5 \%)$.

\begin{tabular}{|c|c|c|c|}
\hline Age & Male & Female & Total \\
\hline $10-20$ & 0 & 0 & 0 \\
\hline $21-30$ & 0 & 0 & 0 \\
\hline $31-40$ & 10 & 16 & 26 \\
\hline $41-50$ & 20 & 23 & 43 \\
\hline $51-60$ & 3 & 7 & 10 \\
\hline$>60$ & 1 & 0 & 1 \\
\hline Total & $\mathbf{3 4}$ & $\mathbf{4 6}$ & $\mathbf{8 0}$ \\
\hline \multicolumn{4}{|l}{ Table 2. Age Wise Distribution of Study Population } \\
\hline
\end{tabular}

In the present study, the commonest age group of patients in the present study is between 40 to 50 years with a range of 30 - 60 years.

\begin{tabular}{|c|c|c|c|}
\hline $\begin{array}{c}\text { Sl. } \\
\text { No. }\end{array}$ & Clinical Feature & $\begin{array}{c}\text { Total } \\
\text { Patients }\end{array}$ & (\%) \\
\hline 1 & Polyarthritis & 80 & 100 \\
\hline 2 & Presence of Deformities & 23 & 28.75 \\
\hline 3 & Subcutaneous Nodules & 22 & 27.5 \\
\hline 4 & $\begin{array}{c}\text { Pleuropulmonary } \\
\text { Manifestations }\end{array}$ & 28 & 35 \\
\hline 5 & Felty's Syndrome & 7 & 8.75 \\
\hline 6 & Vasculitis & 2 & 2.5 \\
\hline 7 & Uveitis & 2 & 2.5 \\
\hline 8 & Pericardial Effusion & 3.75 \\
\hline \multicolumn{3}{|c|}{ Table 3. Frequency of Clinical Features } \\
among Study Population \\
\hline
\end{tabular}

\begin{tabular}{|c|c|c|}
\hline $\begin{array}{c}\text { Sl. } \\
\text { No. }\end{array}$ & $\begin{array}{c}\text { Pleuropulmonary } \\
\text { Manifestation }\end{array}$ & Total \\
\hline 1 & Diffuse Interstitial Fibrosis & 5 \\
\hline 2 & Pleural Effusion & 8 \\
\hline 3 & Tuberculous Pleural Effusion & 4 \\
\hline 4 & Bronchiectasis & 4 \\
\hline 5 & Bronchiectasis with Pleural Nodule & 3 \\
\hline 6 & Bronchial Asthma & 6 \\
\hline 7 & COPD with Pleural & 4 \\
\hline 8 & Thickening and Pleural Nodule & 3 \\
\hline \multicolumn{3}{|c|}{ Table 4. Frequency of Pleuropulmonary } \\
Manifestations among Study Population \\
\hline \multicolumn{2}{|c|}{} \\
\hline
\end{tabular}

\section{DISCUSSION}

All patients in the study group have Rheumatoid factor positivity and radiological features of juxta-articular osteoporosis in the corresponding involved joints. Subcutaneous nodules are present in 22 patients (27.5\%). All 80 patients had polyarthritis, out of which 23 patients $(28.75 \%)$ had deformities, out of which 7 were males and 16 were females. Felty's syndrome was present in 7 patients, uveitis was seen in 2 patients, vasculitis in 2 patients and pericardial effusion was seen in 3 patients. Though Rheumatoid Arthritis is common in females, pleuropulmonary manifestations are relatively common in males. ${ }^{2}$ In the present study out of 80 patients of Rheumatoid arthritis, 28 patients had pleuropulmonary manifestations. Out of 28 patients, 10 were female and 18 were male patients. The prevalence of pleuropulmonary manifestations according to this study is $35 \%$. This is comparable to a similar study conducted at Lucknow. ${ }^{3}$ As documented by Indian Journal of Radiology, the interstitial lung changes affect significant proportion of patients affected with rheumatoid arthritis. Coexisting subcutaneous rheumatoid nodules is a high-risk factor for development of interstitial lung disorder in patients with rheumatoid arthritis. ${ }^{4}$

In the present study 5 patients presented with diffuse interstitial fibrosis, of these 2 patients are elderly having long duration of the disease and had skeletal deformities. They had symptoms of progressive onset of dyspnoea, occasional dry non-productive cough. Chest x-ray of female patient had shown basal reticulonodular infiltrates. Bilateral HRCT of 
both patients showed reticulonodular densities with honeycombing in both lungs, predominantly lower lobes suggestive of fibrosis. There is ground-glass haziness in both lungs. Pulmonary function tests in them showed restrictive pattern. Four patients with rheumatoid arthritis presented with progressive exertional dyspnoea with anaemia and were found to have Felty's syndrome and Caplan's syndrome.

\section{CONCLUSION}

- Rheumatoid arthritis usually appears during third to fifth decades of life.

- Their prevalence increases with age.

- Those patients who had long-standing disease had more articular deformities. Factors associated with poor prognosis in rheumatoid arthritis include insidious polyarticular onset, male patients, extra-articular manifestations.

- Rheumatoid arthritis is prevalent in females, but pleuropulmonary manifestations are common in males.

- Prevalence of pleuropulmonary manifestations is independent of duration of rheumatoid arthritis and presence of levels of antinuclear antibodies and C- reactive protein. But presence of pleuropulmonary manifestations indicate the severity of disease process. They are more common in patients who are having high titres of rheumatoid factor and subcutaneous nodules.

- Among all pleuropulmonary manifestations, pleural effusion is the most prevalent followed by diffuse interstitial fibrosis and bronchiectasis.

\section{REFERENCES}

[1] Linda Rath RA. Lung disease: what you need to know. Available from: http://www.arthritis.org/aboutarthritis/types/rheumatoid-arthritis/articles/lungdisease-rheumatoid-arthritis.php

[2] Chanin K, Vallejo-Manzur F, Sternbach GL, et al. Pulmonary manifestations of rheumatoid arthritis. Hospital Physician 2001:23-8.

[3] Prasad R. Professor and head of department of pulnonary medicine CSM medical University Feb 2009.

[4] Rockall AG, Rickards D, Shaw PJ. Imaging of pulmonary manifestations of systemic disease. Postgraduate Medical Journal 2001;77(912). 